\title{
Surveying for architectural students: as simple as possible - as much as necessary
}

\author{
I. Mayer ${ }^{\mathrm{a}}$ T. Mitterecker ${ }^{\mathrm{a}}$ \\ ${ }^{a}$ Department of History of Architecture and Building Archaeology, TU Wien - irmengard.mayer@tuwien.ac.at, \\ thomas.mitterecker@tuwien.ac.at
}

KEY WORDS: Teaching, Training, Laser Scanning, Photogrammetry, Building Research, Building Archaeology

\begin{abstract}
:
More and more, existing buildings - and particularly historic buildings - are becoming part of the daily business of every architect. Planning and designing in the field of architectural heritage requires not only knowledge of contemporary building techniques, design processes and national and international guidelines, but also a deep understanding of architectural heritage, its evolution and genesis, the building techniques that have been applied, materials used, traditions, etc. In many cases, it is indispensable to perform a detailed building survey and building research to achieve an adequate design concept. The Department of History of Architecture and Building Archaeology of TU Wien has an extensive tradition of building research and over the course of the past 10 years, has developed a teaching workflow to introduce architectural students to building archaeology und surveying methods for building research. A sophisticated, temporally interwoven combination of courses and lectures on different topics related to building archaeology and surveying rapidly gives the architectural students the right tools for this important but often neglected task.
\end{abstract}

\section{FRAMEWORK CONDITIONS}

The study of architecture in Austria is characterised by teaching only the basics of history of architecture, materials science and building services, concentrating mainly on design studios. Although, on the whole, these future architects will not design and build new buildings on greenfield sites, the architecture curriculum at the TU Wien (TUW) does not include any required courses which teach students how to deal with existing architecture, not only in terms of design and construction technology but also in terms of building survey.

Although building survey and building archaeology is included in several studies not only at universities in Austria but in many other countries like Germany, Great Britain and so on, it is hardly possible to get any information about appropriate teaching methods in building survey especially directed to students of architecture. Available literature is dealing even with the correct and detailed workflow in building survey concentrating on the technical part or gives some information on knowledge transfer within different geodetic studies.

To remedy this situation and to give architectural students the possibility to have an insight into building archaeology, the Department of History of Architecture and Building Archaeology offers a series of different courses focusing on surveying and building archaeology. However, none of these courses is a compulsory part of the architectural curriculum, which means that only the most dedicated students take one of these courses. Most of the students have little background knowledge of surveying, limited to very simple hand measurement techniques using tape measures or laser distance meter.

Within the different courses, the department offers several lectures dealing with building survey and building archaeology. They range from exercises in building survey at different levels to the complex "Module History of Architecture and Building Archaeology", which combines four different courses including lectures, exercises and seminars concentrating on building archaeology methods. The main goal of the module is to train the students in building archaeology skills and also in appropriate geometrical surveying techniques for architectural heritage and how to write scientific documentation.

Since the Building Survey I and II courses count for a small number of credits and aim to deliver a presentable building research, the geometrical survey in these courses is limited to tacheometric documentation. In contrast, the intricately coordinated courses of the module can be supplemented with a course on Laser Scanning and Photogrammetry in Historic Building Survey, and the results delivered are on a higher level more of a professional level than a student level - and are often the basis for further scientific research.

\begin{tabular}{|l|c|}
\hline Course & ECTS \\
\hline Building Survey I & 4.0 \\
Building Survey II & 4.0 \\
Module History of Architecture and Building & 10.0 \\
Archaeology: & \\
$\quad \begin{array}{l}\text { Documentation and Analysis of Historical } \\
\quad \text { Architecture }\end{array}$ & 3.5 \\
$\quad \begin{array}{l}\text { Introduction into Methods of Building } \\
\quad \text { Archaeology }\end{array}$ & 2.0 \\
$\quad \begin{array}{l}\text { Seminar in History of Building and Building } \\
\quad \text { Archaeology }\end{array}$ & 2.5 \\
$\quad \begin{array}{l}\text { History of Structural Engineering } \\
\text { Laser Scanning and Photogrammetry in Historic } \\
\text { Building Survey - Methods of Analysis }\end{array}$ & 2.0 \\
\hline
\end{tabular}

Table 1. Survey Courses at the Department of History of Architecture and Building Archaeology

Generally, the courses do not need to be taken in consecutive order, with the exception of the Module History of Architecture and Building Archaeology, where the content of each individual course is perfectly coordinated with the others. 


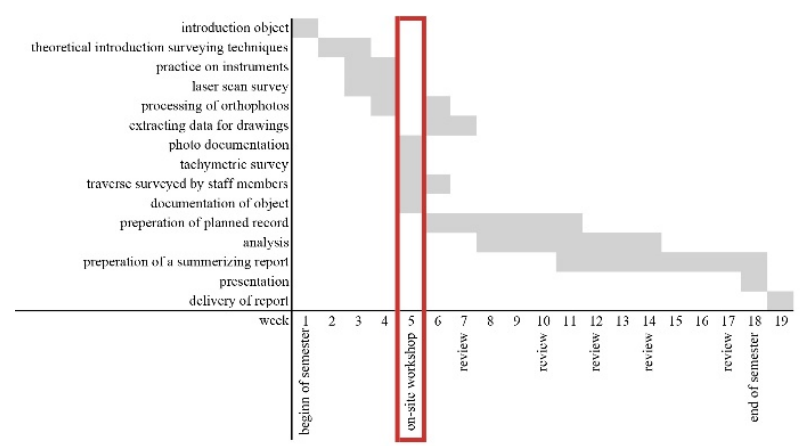

Figure 1. Work schedule

\section{TEACHING WORKFLOW}

Teaching complex surveying methods to students who have no basic skills in surveying techniques is a balancing act between the two questions: "How much or how little knowledge is necessary to understand the principle?" and "How simply can this knowledge be presented without leaving out important information?”. To be able to survey and analyse a building within a one-week workshop, students need to be properly prepared but not overwhelmed with too much information. Therefore it is essential to keep theoretical explanations on surveying techniques as simple as possible and to provide students with a reliable surveying and post-processing workflow.

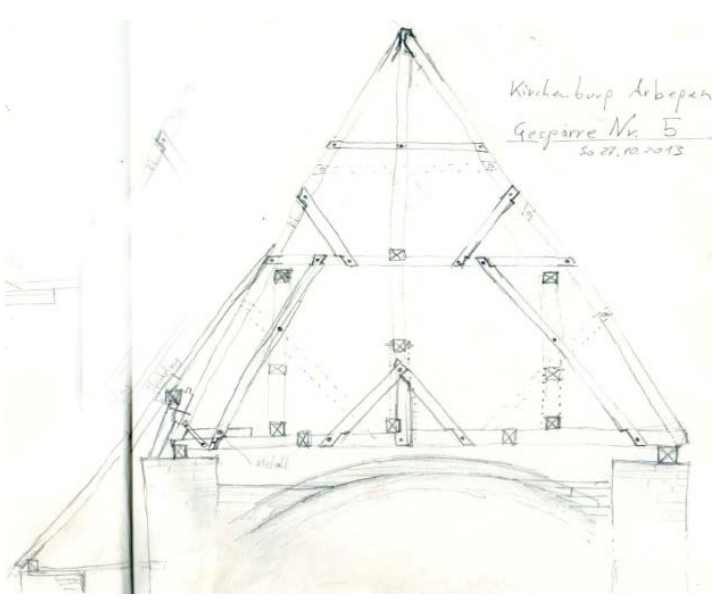

Figure 2. Hand sketch, truss of nave, fortified church, Arbegen, Transylvania (C) Brunner, Malik, Staudinger 2014

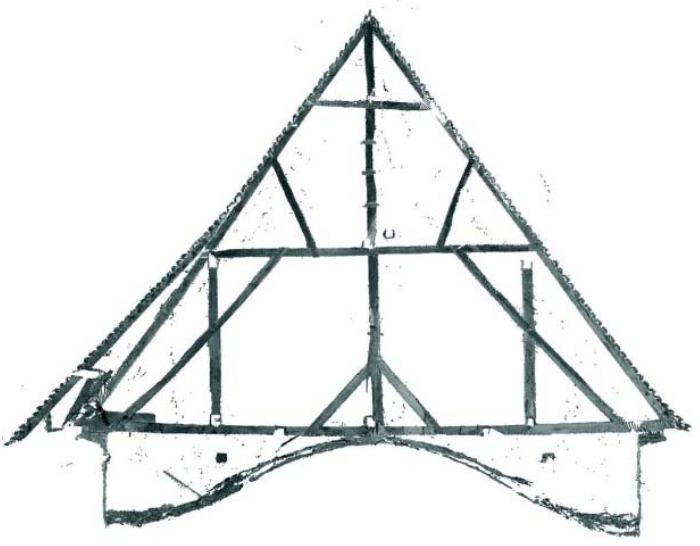

Figure 3. Ortho-projection of point cloud of a principal rafter truss, truss of nave, fortified church, Arbegen, Transylvania (C) Brunner, Malik, Staudinger 2014
At the beginning of each course, the students are introduced to the object to be surveyed, including its historical background and main architectural features. The students are also told what the archaeological building survey is expected to include.

In the preparatory phase of the on-site workshop, a very simplified introductory lecture is presented to the students, covering the technical functionality of the instruments (tachymeter, laser scanner) and measuring principles in general (orientation, registration, etc.). They learn the difference between the single-point measurement of a tachymeter and the automated multi-point measurement of a laser scanner and their advantages and disadvantages of each as applied in building research.

They are also introduced to methods for historical analysis and archival research, scientific-paper writing and the different possibilities offered by analogue and/or digital presentation.

Although he different courses have slightly different teaching approaches, they have all in common a first physical contact, right at the beginning of the course, not only with the object to be surveyed but also with the instruments (laser scanner, tachymeter) which will be used for the geometrical survey.

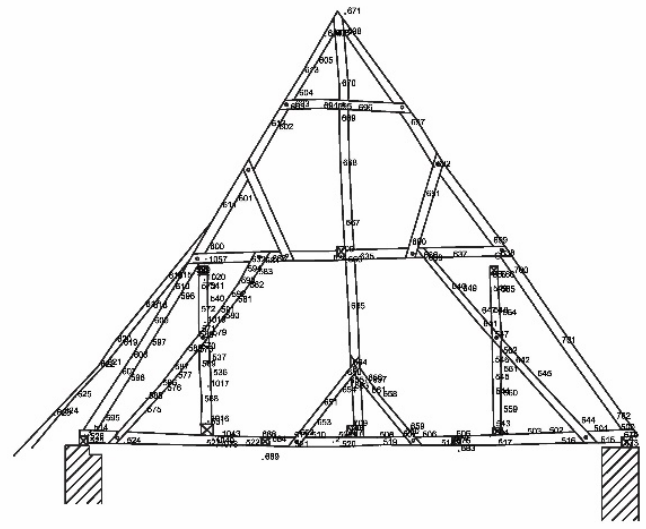

Figure 4. Survey with a total station of a principle rafter truss, truss of nave, fortified church, Arbegen, Transylvania $@$ Brunner, Malik, Staudinger 2014

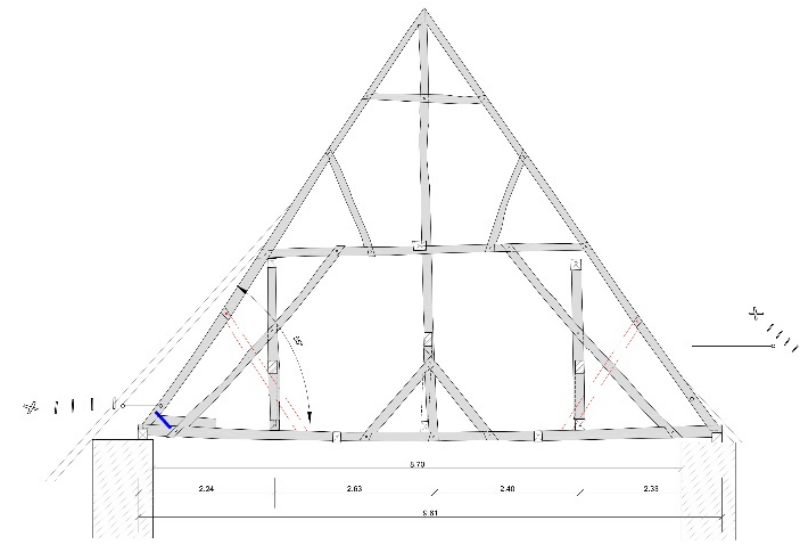

Figure 5. Plan of a principle rafter truss on the basis of the survey using total station and 3D laser scanner completed by hand measurements, truss of nave, fortified church, Arbegen, Transylvania @ Brunner, Malik, Staudinger 2014 
Before starting the survey and documentation itself, students approach the object and make measurement sketches by hand, using a laser distance metre or tape measure. These sketches help them to understand building concepts, room structures, important design features and form the planning basis for the survey and documentation that follows.

Assisted by teachers and tutors, students learn to choose the most suitable instrument positions (on the tachymeter or laser scanner) to survey all features which are relevant for the documentation and analysis and to distributed the necessary targets for orientation and/or registration.

Usually students work in groups of between 2 and 4 people, working on different areas of an object, which results in several individual and independent surveying projects not connected to each other. For consistent results and to facilitate all further analysis measurements, the different groups are connected with a traverse surveyed by teachers and tutors. Generally, this connection takes place at the end of the on-site workshop which allows the students to have an insight one how to spread targets on their own on the one hand but lead to the problem that the individual surveying projects have to be connected later.

\subsection{Tacheometric Survey}

Since our main goal of teaching building archaeology is historical building analysis based on different sources (the building itself, materials, construction details, archives, etc.) the tacheometric survey is only one of these and should not dominate the on-site survey week. It is an integral part of all our surveying courses and delivers the basic information necessary for plan drawing.

Students have already had a first contact with the instrument by setting it up, orientating in an existing coordinate system and performing some measurements.

For ease of handling, the tacheometric survey is supported by TachyCAD software. As an add-on to AutoCad, it allows the students to operate in a familiar CAD-environment without losing the required accuracy of a tacheometric survey.

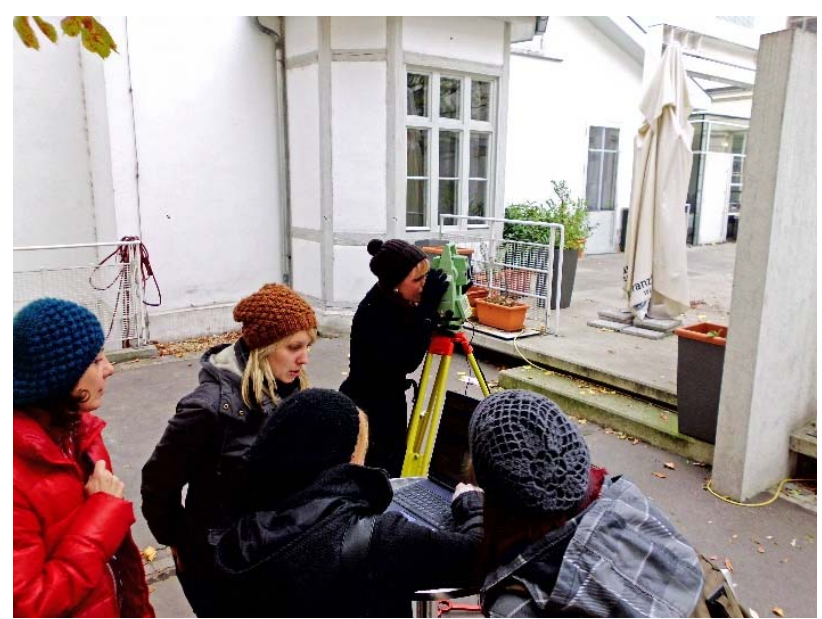

Figure 6. Students first contact with a total station accompanied by teaching staff and tutors, courtyard of TU Wien
After the distribution of tasks, the choice for the positioning of the instrument and setting the control points for the free stationing is taken in consultation with the students. Instrument set-up is always supervised by teachers or tutors.

A detailed and step-by-step handout helps the students with the orientation and the survey itself. Especially in the early stage of the survey, the students always work under supevision so as to avoid common mistakes such as wrong orientation or surveying inappropriate natural points.

\subsection{Laser Scanner Survey}

The large-building archaeological courses are always supported by a laser scanning survey. Two introductory lectures give the students a brief overview of the principles of photogrammetry, laser scanning techniques, the importance of orientation and global registration, the different post-processing steps and possible results adequate for building archaeology.

Although the Laser Scanning and Photogrammetry course is not obligatory, it is strongly recommended that the students of Building Survey II and the Module History of Architecture and Building Archaeology take this course for a complete understanding of the object surveyed. Depending on the object and the required output, documentation with a terrestrial laser scanner can even be performed as part of the on-site workshop or at least two weeks in advance, if processed data is required for the on-site workshop.

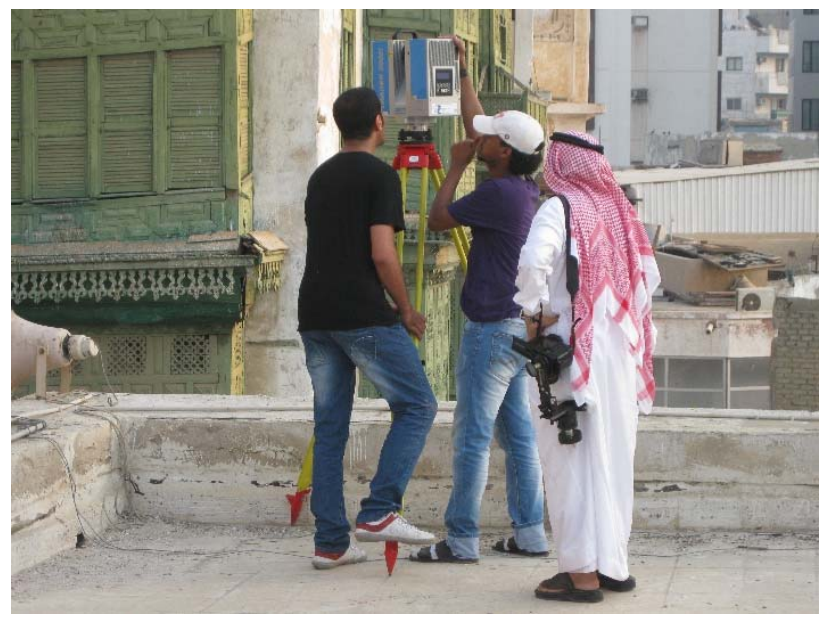

Figure 7. Scanning with Z+F Imager 5006 in Jeddah, Saudi Arabia

After a short introduction to the handling of the instrument ${ }^{1}$ targets for subsequent registration are placed by the students, assisted by teachers or tutors. In consultation with teachers and tutors, the students choose their scan positions and perform the scanning.

The post processing of the laser scan data is performed on the computers at the TU Wien. Students perform not only the registration and orientation on their own, but also the filtering, extraction of sections and orthophotos as well as video sequences to support their building archaeological analysis.

1 Riegl VZ 1000, Zoller+Fröhlich Imager 5010C 


\section{EXAMPLES}

Surveying techniques beyond hand measurements have been part of the building survey courses at the Department of History of Architecture and Building Archaeology for more than 10 years now. In the beginning, the focus was on tacheometric survey supported by a software program called TOTAL ${ }^{2}$. Soon after the, Laser Scanning and Photogrammetry course was introduced to the architectural students attending courses on building archaeology at the TU Wien.

The following sections present some outstanding examples of student projects carried out during building archaeology courses at the Department of History of Architecture and Building Archaeology, with their results and special challenges.

\subsection{Historic Roof Structures of the Vienna Hofburg}

In 2011, students and experts of the Department of History of Architecture and Building Archaeology, in cooperation with the Austrian Federal Monuments Authority and the Austrian Academy of Sciences began a systematic documentation and historical analysis of the historic roof structures of the Vienna Imperial Palace, the Vienna Hofburg, as these remained largely unexplored. The aim of the project is the complete geometrical, constructional and historical recording of all roof truss units of the Vienna Hofburg dating from the medieval period through the renaissance and baroque eras up to the iron roof trusses built in the early $20^{\text {th }}$ century.

Most of the historic roof structures of Vienna Hofburg were surveyed within the framework of several courses and lectures. The combination of traditional and innovative surveying techniques such as hand-measurement, tachymetry or laser scanning formed the basis for the partial, deformation-accurate documentation and the subsequent historical analysis.

In the course of the years, a standardized recording and documentation was developed not only giving the students guidance on how to achieve the desired result, but also to guarantee that all necessary information collected, including:

- Drawings

- Carpenter's marks

- Wooden and metal joints

- Catalogue of rafters

- $\quad$ Erection process

is of a certain standard of quality.

The deformation-accurate documentation of at least one representative part of a truss, spreading from one principal rafter truss to the next principal rafter truss including all paired common rafters, is done in floor planes at the tie beam level and all collar levels, a longitudinal section at the roof ridge plane and/or - if existing - immediately in front of the roofstrengthening plane and two cross sections showing the constructive assembly of one principal rafter truss and one paired common rafter. The geometry and constructive system surveyed on a deformation-accurate level is used for the documentation of the regular system of the entire truss while irregularities such as roof hips have also to be documented to a deformation-accurate level.
Information on the wooden joints is included in drawings on a scale of 1:50 and also in drawings on a scale of 1:10 and exploded views of every single joint. Carpenter's marks are inscribed element by element into the graphic documentation using ground plans. A catalogue of rafters summarizes all the data collected on every rafter (geometry, position, joints, carpenter's marks, results of dendrochronological analysis, etc.), deviation from the standard rafter, destructions, repairs, damages, etc.

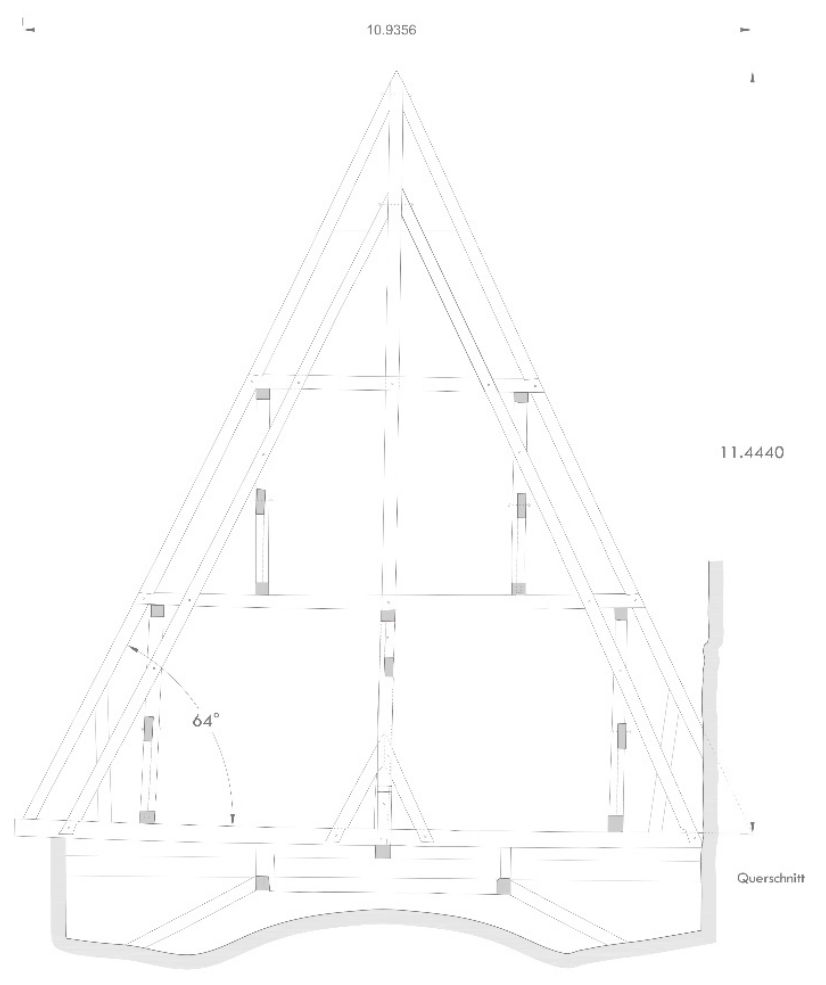

Figure 8. Vienna Imperial Palace Chapel, cross section of a principal rafter truss (C) Herrmann, Knauer, Slupetzky 2011

In most of the surveys, data acquisition was performed using a total station supplemented by hand measurements. To date, only the surveys of three wings of the Hofburg (Augustinian wing, great St. Michael cupola, side wings of the State Hall, and National Library) were based on a terrestrial laser scanner survey performed by the students. Since the CAD drawings of the roof trusses resulting from the 3D data were developed in the course of the semester and not on-site, data acquisition was done in the week of the on-site workshop.

So far, 30 of the 40 main wooden structure units of the Vienna Hofburg have been architecturally documented (excluding the connecting small wooden and metal roofs). This and the fact that the roofs have been surveyed and documented as part of courses and lectures with different ECTS over several years, has created a significant problem: the individual surveys are only very rarely connected to each other. At the end of the acquisition process, a method for a proper tacheometric connection of all the individual surveys will be developed and implemented. A closed traverse throughout the roofs of the entire Vienna Hofburg will guarantee an overall floor plan including all additional information such as

2 Tachymetrische objektorientierte teilautomatische Laservermessung - tacheometric object-oriented semi automatic laser survey; by Ruhr Universität Bochum 
that on joints, carpenter's marks and dating based on dendrochronological analysis of all surveyed roof structures.

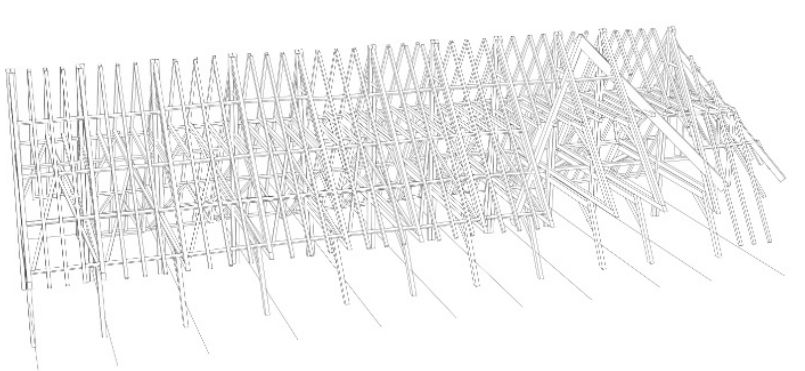

Figure 9. 3D reconstruction of the truss of the Augustinian wing, Hofburg Vienna, based on a 3D laser scan survey (c) Karassew 2016

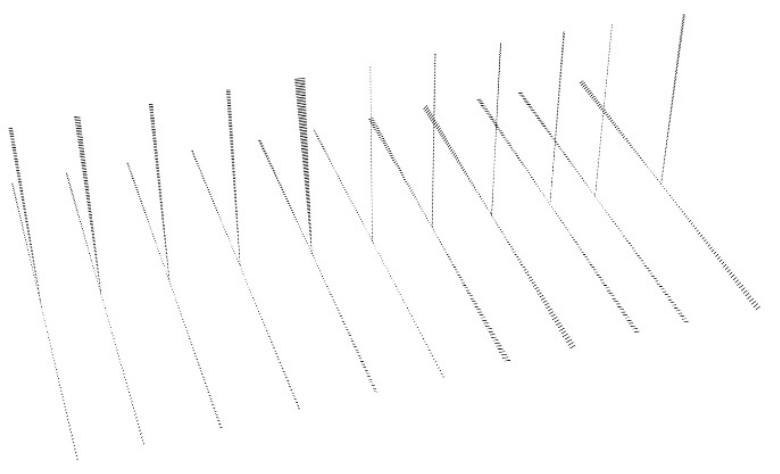

Figure 10. Geometrical deviation from the regular system of the principal rafter trusses at Augustinian wing, Hofburg Vienna

(C) Karassew 2016

\subsection{St. Michael's Church, Vienna}

Geographically and historically very close to the Vienna Hofburg is the early Gothic church of St. Michael, which was the parish church of the Imperial Court until the end of the $18^{\text {th }}$ century. Within the past six years, three building research projects have been implemented at St. Michael's including a documentation and analysis of the roof (central nave, aisles, choir), the arches and all visible wall parts in the nave, some storeys of the belfry as well as in the renaissance crypt where in some parts the medieval foundation is still visible.

Although the spatial extent of the church is not as large as that of the Vienna Hofburg, the typology and architecture of the building as well as the survey areas (e.g. access to the roofs of the aisles is only possible through two very narrow separate tower staircases) require a detailed planning of the tachymetric survey executed by the teaching staff with the support of the students. For example, a traverse connecting the interior of the church with the crypt and the main truss was only possible through very small roof windows.

The last survey at St. Michael's, in autumn 2016, covered the historic masonry visible on the walls above the gothic vaults, in the belfry and in the crypt. One of the main goals was a standardized masonry catalogue for better comparison of the different types of stonework applied over time. The catalogue required a very detailed material and damage mapping on a scale of 1:20 of all exemplary masonry types. Since the data acquisition by laser scanner and the processing of orthophotos done by the students took place two weeks before the on-site workshop, in the documentation week, the students were able to focus on the structural, material and damage analysis and work out a conclusive building history.

One of the particular challenges was the combination of 3D laser scan data surveyed in the course of two different building research efforts by different students working on diverse research questions, in the space of two years. Due to external circumstances, it was not possible to mark the polygon points permanently which complicated the merging of the two different 3D data sets. The fact that at least some of the targets of the first survey were still in place in the main truss at the time of the second survey and some areas were scanned yet again helped to 
generate a registered overall point cloud representing around $80 \%$ of the entire church (crypt, nave, transept, chancel, organ gallery, parts of the belfry, roof structures and parts of the exterior).

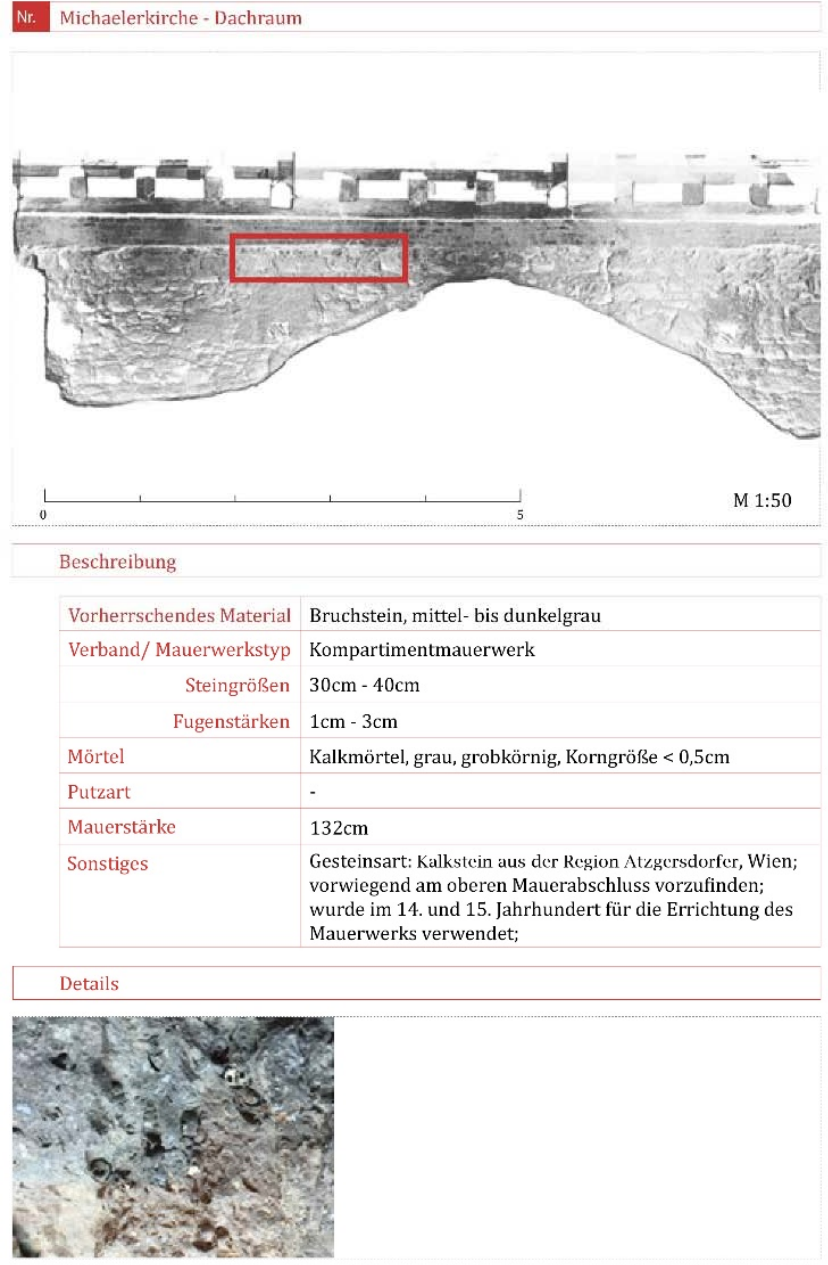

\subsection{Al Nawar, Jeddah}

In autumn 2011, a joint workshop entitled “Traditional Architecture Recorded by Means of Building Archaeology in Saudi Arabia" 3 took place in Jeddah, Saudi Arabia. The aim of the workshop was knowledge transfer about details of historic buildings in Jeddah from the King Abdul Aziz University (KAU) side and methods for building archaeology research from the TU Wien side. In addition to the research on historic architecture in Al Balad, the historical part of Jeddah, one ordinary residential building in the heart of $\mathrm{Al}$ Balad was chosen for a detailed building archaeological survey. The KAU team comprised students and teaching staff from the fields of architecture, landscape planning and geodesy.

One of the major challenges of this workshop was the fact that the scientists and researchers from TU Wien were all female and male students and teaching staff were unused to being given instructions by women. The fact that building archaeology is yet not established in Saudi Arabia, and neither the students nor the teaching staff of KAU have ever done any kind of detailed

3 Part of the international research project entitled "Documentation and Analysis of Traditional Architecture of Saudi Arabia” between King Abdul Aziz University (KAU), Jeddah and the TU Wien building research, led in the beginning of the four-week workshop to a number of misunderstandings.

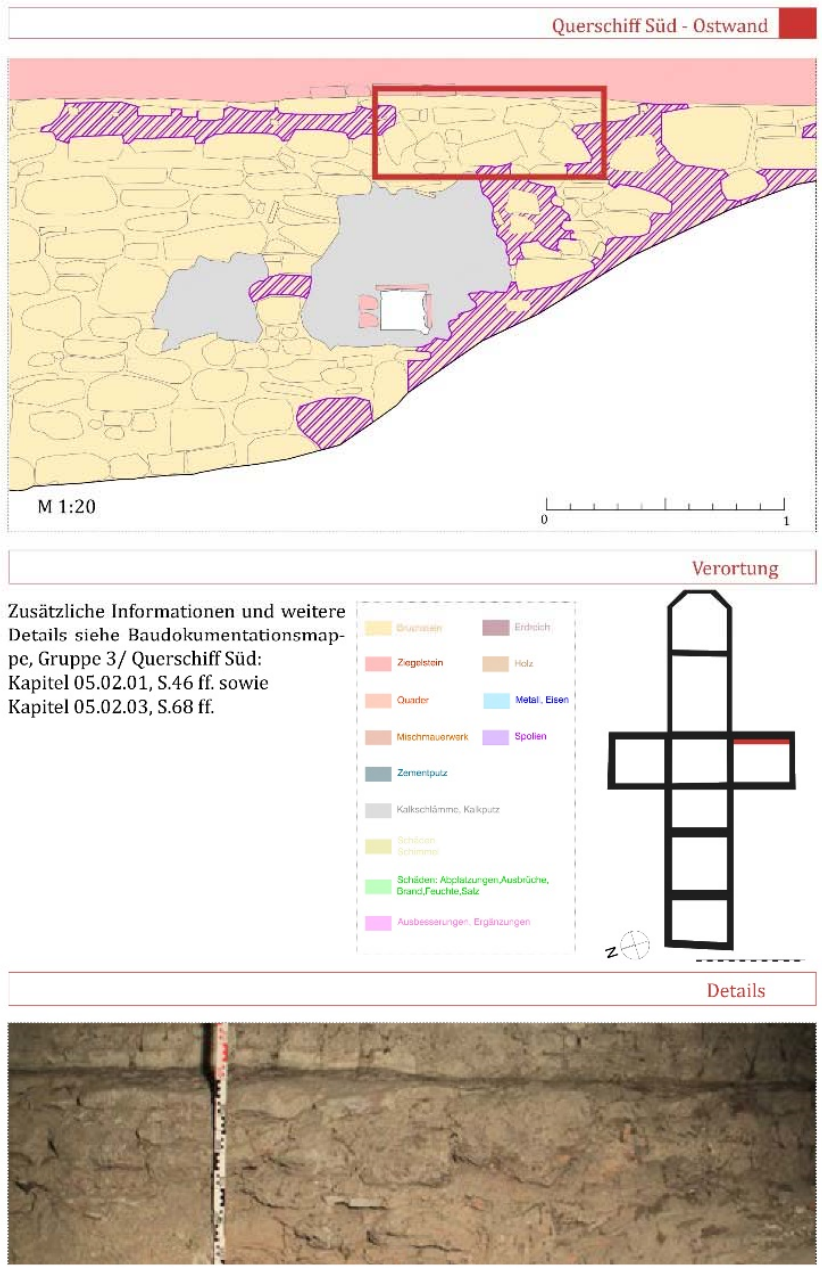

Figure 12. Masonry catalogue, St. Michael, Vienna (C) Grausam, Tamm, Vucenovic 2017

The beginning of the workshop was used to introduce and present the principles of building research and methods of documentation and analysis, as well as the history of building research, concepts of building inventories and the applied guidelines for the preservation of historical monuments developed in Austria.

A very close cooperation between KAU students and TUW teaching staff allowed a precise, detailed and comprehensive documentation of Al Nawar house, the residential building selected. The four-week workshop in Jeddah was mainly focused on the geometrical survey and collection of important information on the selected object and some buildings for comparison.

A 3D survey using GPS, three total stations and two different laser scanners (Z+F Imager 5006i from TU Wien, Leica ScanStation C10 from KAU) formed the basis for the resulting planning record. The documentation, consisting of scaled hand drawings of special architectural features, damage and material 
mapping in pictures and orthophotos, structural and constructional analysis and the review of existing plans and texts done mainly by the KAU students with support from the TUW researchers provided all the necessary information for the building research. At the end of the workshop, students were briefly introduced to the post-processing workflow.

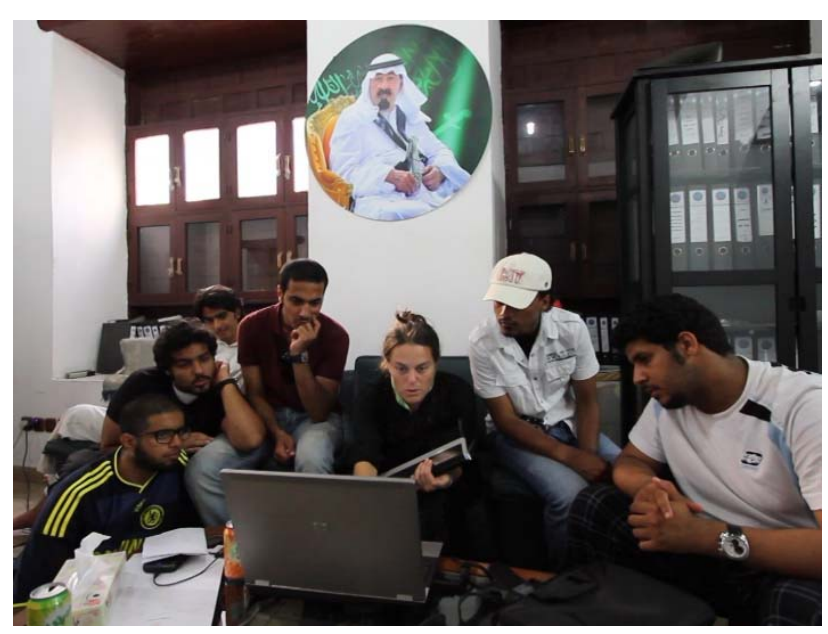

Figure 13. cooperation between students of KAU and TUW teaching staff

The collected data were processed, prepared and analysed back in Vienna by the TUW researchers, with the support of excellent students experienced in building research.

\section{CONCLUSION}

Years of experience in surveying not only historic roof structures but also vernacular architecture, World Heritage or even contemporary architecture within the framework of student courses led to the realisation that the surveying workflow developed is perfectly suited to the requirements of architectural students. It gives students of architecture the unique opportunity to have first-hand knowledge of surveying techniques and concepts without losing their direction in too many technical details. With this knowledge, future architects can more easily estimate and evaluate survey costs and output and will be able to adapt their designs to the existing structures.

However, the student-to-teacher-ratio has to stay low to guarantee the required knowledge transfer and to hold the quality of the teaching and the output as high as possible. Hands-on experience is still the best way to learn and should be intensified in all fields of the study of architecture.

\section{REFERENCES}

Herbig, U., Mayer. I., et.al. 2014. Integration of Three Dimensional Data From Unknown Origin on the Example of a Traditional Residential Building in Al-Balad, Jeddah, Saudi Arabia. In: ISPRS Annals - Volume II-5, 5 p

Herbig, U., Jäger-Klein C., etl.al. 2013.TRABASA - Traditional Architecture Recorded by Means of Building Archaeology in Saudi Arabia: Workshop in Jeddah. In: The International Archives of the Photogrammetry, Remote Sensing and Spatial Information Sciences - Volume XL-5/W2, p 331-336
Mayer, I., Styhler-Aydın, G., et al. 2012. Integrated Building Survey for Detailed Recording of Cultural Heritage in Jeddah, Saudi-Arabia, in: Research Papers on Architectural Heritage: Research \& Heritage 2, Research Papers for the $2^{\text {nd }}$ National Built Heritage Forum”, Dammam 2012

Styhler-Aydın, G., et.al. 2016. The Historic Roof Structures of the Vienna Hofburg: An Innovative Interdisciplinary Approach in Architectural Sciences Laying Ground For Structural Modeling. In CD-Rom Proceedings of The World Conference on Timber Engineering (WCTE 2016), J. Eberhardsteiner, W. Winter, A. Fadai, M. Pöll (eds.); TU Wien, Wien 2016 